\title{
Paleogene of the Magura Nappe adjacent to the Pieniny Klippen Belt between Szczawnica and Krościenko (Outer Carpathians, Poland)
}

\author{
Jan Golonka, Anna Waśkowska \\ AGH University of Science and Technology, Faculty of Geology, Geophysics and Environmental Protection, al. Mickiewicza 30, \\ 30-059 Krakow, Poland; e-mail: jgolonka@agh.edu.pl,waskowsk@agh.edu.pl
}

(C) 2014 Authors. This is an open access publication, which can be used, distributed and reproduced in any medium according to the Creative Commons CC-BY 4.0 License requiring that the original work has been properly cited.

Received: 12 November 2014; accepted: 16 February 2015

\begin{abstract}
The present authors investigated the Paleogene deposits of the internal zone of the Magura Basin known as the Krynica Subunit or Krynica zone in Poland. These deposits crop out in the peri-Pieniny zone, in the area between Szczawnica and Krościenko. The oldest flysch deposits belong to the Paleocene - Lower Eocene Szczawnica Formation. This formation is covered by thin-bedded turbidites of the Eocene Zarzecze Formation locally with intercalations of the thick-bedded sandstones of the Krynica Member and Łącko-type marls. The youngest rocks in this area belong to the Eocene-Oligocene Magura Formation. The Zarzecze Formation occupies a large part of the Krynica zone of the Magura Nappe border structure. Some deposits previously distinguished as the Szczawnica Formation were transferred to the Zarzecze Formation. The foraminiferal assemblages confirm the Eocene age of these deposits.
\end{abstract}

Keywords: Magura Nappe, Krynica zone, peri-Pieniny zone, Paleocene-Eocene, lithostratigraphy, foraminifera

\section{INTRODUCTION}

The present authors investigated recently the Eocene deposits within the Bystrica and Rača zones of the Magura Nappe in Poland and Slovakia. This research resulted in redefinition of the lithostratigraphic units, especially the Beloveža Formation (Golonka \& Waśkowska 2012). In this study were adopted a similar approach to re-examine the internal zone of the Magura Basin known as Krynica Subunit (zone) in Poland or Oravska Magura Subunit (Nappe) in Slovakia (e.g., Kováč \& Plašienka 2002, Ślączka et al. 2006, and references therein). Another classic lithostratigraphic unit, the Magura Formation was established in this zone by Paul (1868, see also Ślączka et al. 2006). The flysch deposits below this formation were named by
Uhlig (1890) as the "Boundary Flysch". The names Hieroglyphic Beds, Szczawnica Beds, Submagura Beds, Beloveža Beds, Inoceramian Beds, and Ropianka Beds have been used by different authors in the area (Birkenmajer 1957, Bogacz \& Węclawik 1962, Watycha 1963, Oszczypko 1979, see also summary by Chrustek et al. 2005). Birkenmajer \& Oszczypko (1989) provided a formal lithostratigraphic scheme of the Krynica Subunit. They described the Eocene Zarzecze Formation below the Magura Formation. However, only the Szczawnica Formation was distinguished on the map of the area between Krościenko and Szczawnica (Birkenmajer \& Oszczypko 1989). Chrustek et al. (2005) mapped the Eocene Zarzecze Formation on the southern slope of Dzwonkówka Mountain. The present authors supplement their work by detailed 
biostratigraphic investigation and cartographic survey of this area especially of the flysch deposits in Ścigocki stream on the adjacent banks of the Dunajec River.

\section{OUTLINE OF GEOLOGY}

The Magura Nappe is the largest tectonic unit of the Western Carpathians (Fig. 1) and is linked with the Rheno-Danubian flysch of the Eastern Alps. During the overthrust movements, the Magura Nappe was completely uprooted from its substratum along the ductile Upper Cretaceous rocks. On the base of facial differentiation of the Paleogene deposits the Magura Nappe has been subdivided into four facies-tectonic subunits: the Krynica, Bystrica, Rača and Siary (e.g., Koszarski et al. 1974, Cieszkowski et al. 1985, Oszczypko 1992, Ślączka et al. 2006, and citation therein).

The rocks of the Magura Nappe were deposited within the Magura Basin, which originated during Jurassic time. Parts of these deposits were incorporated into the Pieniny Klippen Belt tectonic structure. The remaining parts belong to the Magura Nappe, which is separated from the Pieniny Klippen Belt in Poland and adjacent part of Slovakia by a steeply-dipping southward strike-slip boundary (Ślączka et al. 2006). The Krynica Subunit is located between the Pieniny Klippen Belt and the Bystrica Subunit. This subunit includes uppermost Cretaceous-Oligocene flysch rocks in the area adjacent to the Pieniny Klippen Belt in Poland known as the peri-Pieniny klippen zone (Watycha 1963, Golonka \& Sikora 1981). The older, Jurassic-Cretaceous deposits, are known only from the olistoliths within the flysch (e.g., Cieszkowski et al. 2009, Golonka et al. 2010, 2015, and citation therein).

The oldest flysch deposits recognized in the Krynica Subunit in the Krościenko-Szczawnica (see Alexandrowicz et al. 1966, 1982, Cieszkowski \& Oszczypko 1985) area belong to the Paleocene-Lower Eocene Szczawnica Formation. The older, Cenomanian-Senonian rocks are not exposed in this area, they have been found in the Obidowa IG-1 well (e.g. Cieszkowski 1985). This
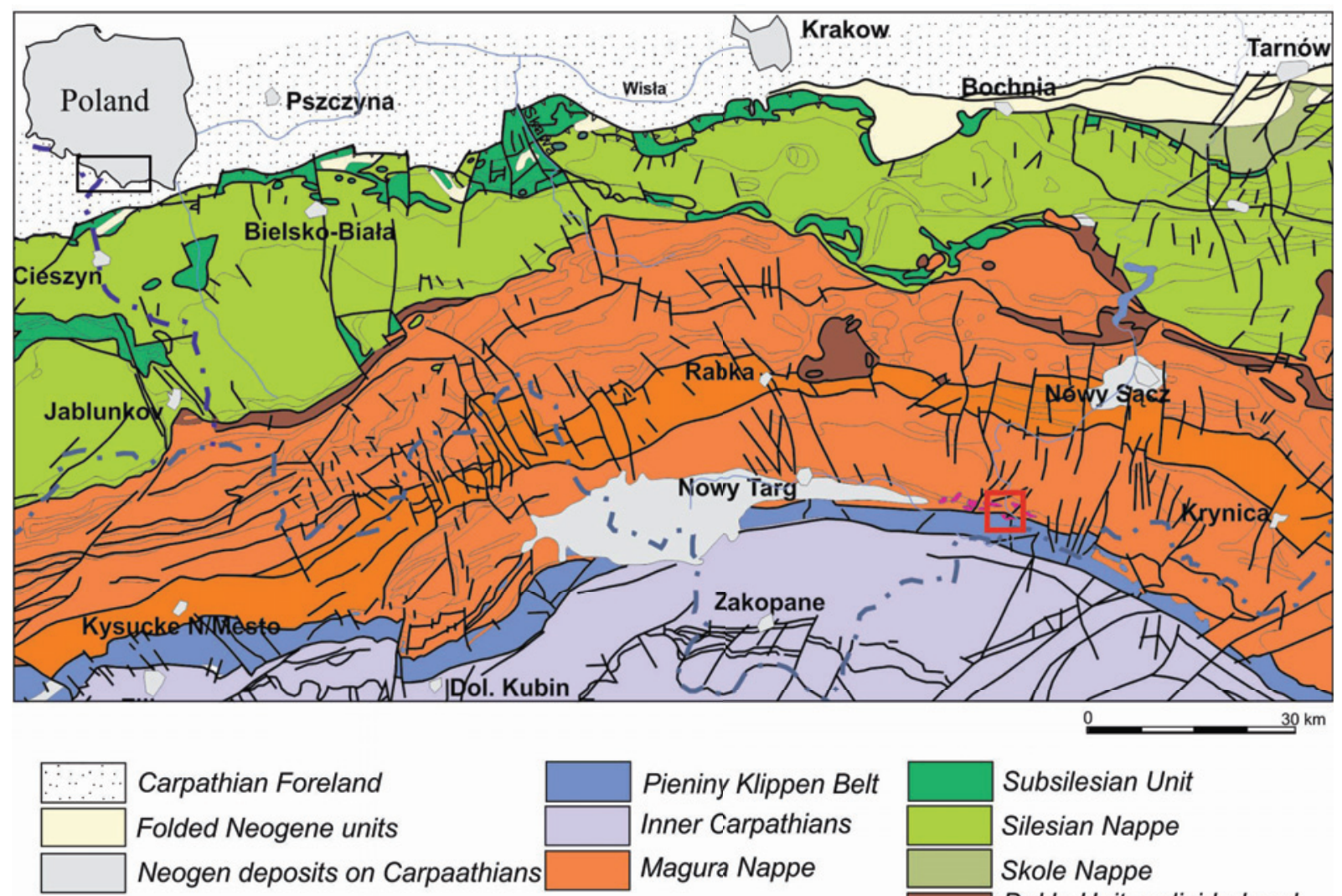

Pieniny Klippen Belt
Inner Carpathians
Magura Nappe

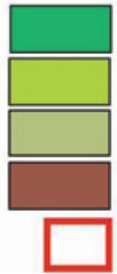

Subsilesian Unit Silesian Nappe Skole Nappe Dukla Unit undivided and others Foremagura units Study area

Fig. 1. Location of the studied section on the tectonic sketch-map of the Carpathians (map after Lexa et al. 2000) 
formation is built of thin- and medium-bedded flysch with intercalations of thick and very hard sandstones locally forming the Lower Eocene Życzanów Member. The Szczawnica Formation is covered by thin-bedded turbidites of the Eocene Zarzecze Formation locally with intercalations of the Łącko-type marls (Chrustek et al. 2005). The Krynica Member consisting of thick-bedded sandstones occurs locally within the Zarzecze Formation. The Zarzecze Formation is covered by the Eocene-Oligocene Magura Formation. The thick-bedded sandstones of the Piwniczna Sandstone Member, the lower part of the Magura Formation, occur in the investigated area (Kulka et al. 1987, 1991, Chrustek et al. 2005).

The Beskid Sądecki Mountains display an inverse geomorphology. Synclines build the mountain tops. The large syncline with the Piwniczna Sandstone Member forms the Dzwonkówka-Radziejowa mountain range south of Krościenko and Szczawnica. The anticlines with the Szczawnica Formation form the slopes and the valleys. The relatively soft flysch complexes of the Szczawnica and Zarzecze formations are often strongly folded and disharmonic, sometimes the strata are overturned (Chrustek et al. 2005).

The large anticline with the Szczawnica Formation occurs between Dzwonkówka and the Dunajec River in the Ścigocki stream area. Andesite intrusions are located in this area (Kulka et al. 1987, 1991, Birkenmajer \& Oszczypko 1989, Chrustek et al. 2005). The Ścigocki anticline is cut westward by the Zawiasy dextral fault, bordering the Pieniny Klippen Belt. The tectonic character of the Polish-Slovak section of the Pieniny Klippen Belt is mixed. Both strike slip and thrust components occur here (e.g., Golonka \& Rączkowski 1984, Jurewicz 2005). In general the subvertically arranged Jurassic-Lower Cretaceous basinal facies display tectonics of a diapiric character that originated in the strike-slip zone between the two plates.

\section{MATERIAL AND METHODS}

The present authors conducted detailed fieldwork supplemented by remote sensing techniques (geological interpretation of aerial photographs, satellite images, radar images, condensed contour maps and DEM - Digital Elevation Models) as well as stratigraphic studies, sedimentologic studies, and analysis of local tectonics. Detailed field mapping enabled the identification of the best localities for micropalaeontological sampling. Micropaleontological studies were focused on foraminiferal biostratigraphy. For this purpose the material was collected from Paleogene deposits of the Magura Nappe, Krynica Subunit in the peri-Pieniny zone. Sampled sections were located in the upper part of the Ścigocki stream valley as well as in the bank of the Dunajec River, slightly below the St. Kinga Chapel (Fig. 2). Nine mudstone and marly samples were taken from mudstone-shale-marl complexes occurring within flysch deposits.

The examined sediments were prepared by using standard micropalaeontological methods. Samples of $0.5 \mathrm{~kg}$ dry mudstones or marls were put into a maceration process in water solution of Glaubert's Salt $\left(\mathrm{Na}_{2} \mathrm{SO}_{4}\right)$. Disintegrated samples were washed through a set of sieves ( $68 \mu \mathrm{m}$ screen) and dried. Microfossils were picked from the received residue. The foraminifera are the dominant microfossils present, and fish teeth, piritized radiolarian infillings and echinoderm spines were present as accessory components.

All specimens of foraminifera were selected from each sample and were treated as an assemblage. Poorly-preserved agglutinated foraminifera dominate in the assemblages. Calcareous foraminifera represent the marginal component of the whole group or are absent, except poorly preserved planktonic assemblage in sample no. 25/1/12 (Tab. 1). The assemblages of agglutinated foraminifera have a deep-water character. The preservation of the fauna is unsatisfactory, specimens are deformed, compressed, silicified with corroded surfaces. The number of specimens per sample varies from a dozen or so to more than 1500 (Tab. 1). Foraminifera were taxonomically identified to the rank of species or genus. The specimens were analyzed and partly graphically documented using binocular microscope Nikon LV100POL (in the Department of General Geology and Geotourism WGGiOŚ AGH and Scanning Microscope FEI QUANTA 200 FEG (Scanning Microscopy Laboratory WGGiOŚ AGH). The foraminifera are housed at AGH Kraków (Micropress Europe) in the author's collection. 


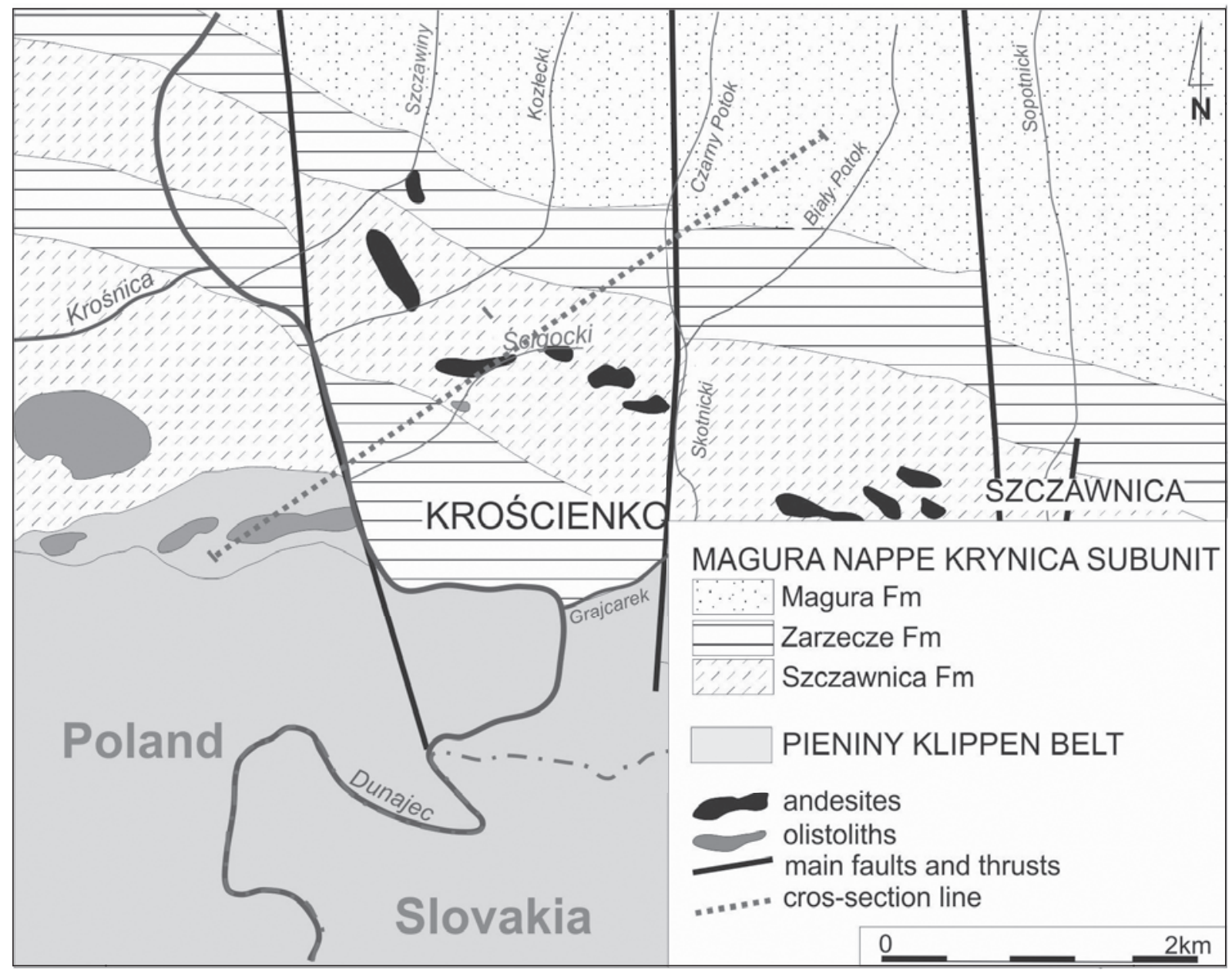

Fig. 2. The geological map of the Krościenko - Szczawnica area

\section{Table 1}

Taxonomical composition of foraminiferal samples (samples position in Figure 4)

\begin{tabular}{|c|c|c|c|c|c|c|c|c|c|c|}
\hline $\begin{array}{c}\text { Type } \\
\text { of } \\
\text { foraminifera }\end{array}$ & Sample number & 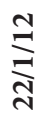 & $\frac{\stackrel{N}{N}}{\stackrel{N}{N}}$ & 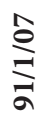 & $\frac{\hat{o}}{\stackrel{N}{a}}$ & $\frac{\hat{m}}{a}$ & $\frac{\hat{f}}{\frac{1}{f}}$ & $\frac{\hat{2}}{\frac{1}{n}}$ & 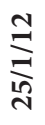 & 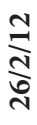 \\
\hline \multirow{13}{*}{ 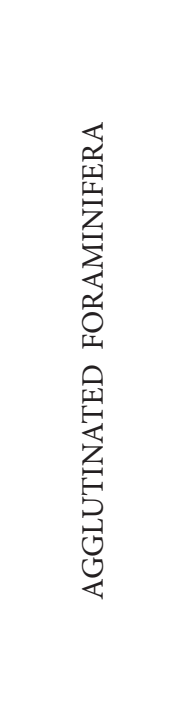 } & Ammodiscus tenuissimus Grzybowski & & I & I & & & I & & & \\
\hline & Ammodiscus peruvianus Berry & & & & I & & I & & & I \\
\hline & Ammodiscus planus Loeblich & & & & I & & & & & \\
\hline & Ammodiscus spp. & & & & & & & I & & \\
\hline & Ammosphaeroidina pseudopauciloculata (Mjatliuk) & & I & I & & I & & $\mathrm{V}$ & & \\
\hline & Annectina biedai Gradstein et Kaminski & & I & & & & & & & \\
\hline & Annectina grzybowskii (Jurkiewicz) & & I & & & & & & & \\
\hline & Arenoulimina dorbignyi (Reuss) & & & & & & & & & I \\
\hline & Arthrodendron sp. & & I & & & & I & & & \\
\hline & Bathysiphon and Nothia div. sp. & I & $\mathrm{H}$ & $\mathrm{V}$ & $\mathrm{X}$ & $\mathrm{X}$ & I & $\mathrm{H}$ & & $\mathrm{Z}$ \\
\hline & Conglophragmium irregulais (White) & & I & I & & & I & I & & \\
\hline & Cribrostomoides sp. & & & $\mathrm{V}$ & I & & I & I & & \\
\hline & Cystammina sp. & & & & & & & I & & II \\
\hline
\end{tabular}


Table 1 cont.

\begin{tabular}{|c|c|c|c|c|c|c|c|c|c|}
\hline \multirow{40}{*}{ 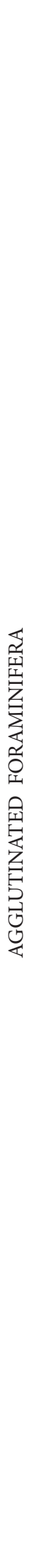 } & Dolgenia sp. & & I & I & I & 1 & I & & \\
\hline & Glomospira charoides (Jones et Parker) & & $\mathrm{X}$ & II & $\mathrm{V}$ & $\mathrm{X}$ & $\mathrm{V}$ & & $\mathrm{H}$ \\
\hline & Glomospira glomerata (Grzybowski) & & & & & & I & & $\mathrm{V}$ \\
\hline & Glomospira cf. diffundens Cushman et Renz & & & & & I & & & \\
\hline & Glomospira gordialis (Jones et Parker) & I & $\mathrm{X}$ & II & I & II & II & & II \\
\hline & Glomospira irregularis (Grzybowski) & & & I & & I & & & I \\
\hline & Glomospira serpens (Grzybowski) & & & I & & & & & \\
\hline & Haplophragmoides cf. kirki Wickenden & & & & & & I & & \\
\hline & Haplophragmoides kirki Wickenden & & I & & & I & & & \\
\hline & Haplophragmoides horridus (Grzybowski) & & & & & I & & & \\
\hline & Haplophragmoides walteri (Grzybowski) & & & & & I & I & & I \\
\hline & Haplophragmoides mjatliukae (Maslakova) & I & & & & & & & \\
\hline & Haplophragmoides porrectus Maslakova & & I & I & $\mathrm{V}$ & & & & \\
\hline & Haplophragmoides cf. porrectus Maslakova & & II & & I & I & & & \\
\hline & Haplophragmoides sp. & & 1 & & & I & I & & \\
\hline & Hormosina velascoensis (Cushman) & I & & & & & & & \\
\hline & Hormosina trinitatensis Cushman et Renz & & & & I & & I & & II \\
\hline & Hormosinella carpenteri Brady & & I & I & & I & & & $\mathrm{V}$ \\
\hline & Hyperammina sp. & & & & I & & & & \\
\hline & Karrerulina conversa (Grzybowski) & I & & & & & $\mathrm{I} ?$ & & $\mathrm{Z}$ \\
\hline & Karrerulina coniformis (Grzybowski) & & & I & & & & & $\mathrm{W}$ \\
\hline & Karreriella sp. & & & & & & & $\mathrm{x}$ & \\
\hline & Paratrochamminoides acervulatus (Grzybowski) & I & & & & & & & \\
\hline & Paratrochamminoides contortus (Grzybowski) & $\mathrm{V}$ & & & I? & & I & & $\mathrm{W}$ \\
\hline & Paratrochamminoides deflexiformis (Noth) & & & & I & & & & \\
\hline & Paratrochamminoides heteromorphus (Grzybowski) & II & & & & & & & \\
\hline & Paratrochamminoides mitratus (Grzybowski) & I & & & & & & & \\
\hline & Paratrochamminoides and Trochamminoides div. sp. & & & & & I & II & & $\mathrm{Z}$ \\
\hline & Placentammina placenta (Grzybowski) & I & II & II & II & & I & & \\
\hline & Praesphaerammina gerochi Hanzlikova & & $\mathrm{X}$ & I & I & I & & & \\
\hline & Praesphaerammina subgaleata Vasicek & & & I & $\mathrm{I} ?$ & & & & \\
\hline & Psammosiphonella cylindrica (Glaessner) & & & & & & & & $\mathrm{X}$ \\
\hline & Pseudonodosinella elongata (Grzybowski) & & I & & & & & & \\
\hline & Pseudonodosinella nodulosa (Brady) & & I & & & & & & \\
\hline & Recurvoides div. sp. & $\mathrm{V}$ & Z & $\mathrm{X}$ & $\mathrm{W}$ & $\mathrm{X}$ & $\mathrm{W}$ & & $\mathrm{F}$ \\
\hline & Remesella varians (Glaessner) & I & & & & & & & \\
\hline & Reophax duplex Grzybowski & & & & & & I & & I \\
\hline & Reophax pilulifer Brady & & & & I & & & & $\mathrm{I}$ \\
\hline & Reticulophragmium amplectens (Grzybowski) & & & & I & & & & \\
\hline & $\begin{array}{l}\text { Reticulophragmium amplectens (Grzybowski) - juvenile } \\
\text { form }\end{array}$ & & I & & & II & I & & \\
\hline
\end{tabular}


Table 1 cont.

\begin{tabular}{|c|c|c|c|c|c|c|c|c|c|c|}
\hline $\begin{array}{c}\text { Type } \\
\text { of } \\
\text { foraminifera }\end{array}$ & Sample number & 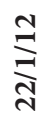 & $\frac{\stackrel{N}{d}}{\stackrel{d}{d}}$ & $\stackrel{\hat{\sigma}}{\vdots}$ & $\frac{\hat{a}}{\text { a }}$ & $\frac{\hat{m}}{a}$ & 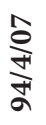 & $\frac{\hat{2}}{\frac{1}{10}}$ & 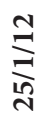 & 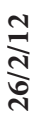 \\
\hline \multirow{12}{*}{ 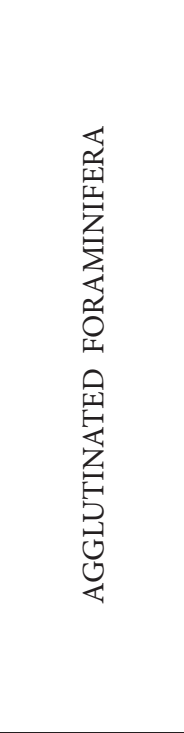 } & Spiroplectammina navarroana Cushman & & & & & & & I & & \\
\hline & Spiroplectammina spectabilis (Grzybowski) & & & I & & & & & & I \\
\hline & Subreophax splendidus (Grzybowski) & & & & & & I & & & \\
\hline & Subreophax scalaris (Grzybowski) & & & I & & & & & & $\mathrm{V}$ \\
\hline & Subrepohax pseudoscalaris Grzybowski & & I & & I & I & & I & & \\
\hline & Trochammina sp. & & & & & II & I & I & & \\
\hline & Trochammina globigeriniformis (Jones et Parker) & & I & & & & & & & \\
\hline & Trochammina cf. umiatensis Tappan & & & & & II & & & & \\
\hline & Trochamminoides grzybowskii Kaminski et Geroch & & I & & & & & & & \\
\hline & Trochamminoides proteus (Karrer) & & & & & & I & & & \\
\hline & Trochamminoides subcoronatus (Grzybowski) & & I & & & & & & & $\mathrm{X}$ \\
\hline & Trochamminoides variolarius (Grzybowski) & & I & & & & & & & $\mathrm{V}$ \\
\hline \multirow{10}{*}{ 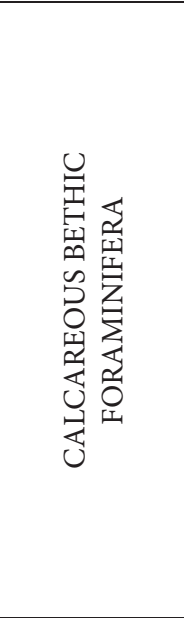 } & Cibicidoides praemundulus Berggren et Miller & & & & & & I & & $\mathrm{x}$ & I \\
\hline & Cibicides sp. & & & I & & & I & I & $\mathrm{x}$ & \\
\hline & Dentalina and Nodosaria spp. & & & & & & & & $\mathrm{x}$ & \\
\hline & Fissurina sp. & & & & & & & & $\mathrm{x}$ & \\
\hline & Eponides umbonatus (Reuss) & & & & & & & & & I \\
\hline & Lenticulina sp. & & & & & & & & $\mathrm{x}$ & \\
\hline & Gavelinella sp. & & & & & & & & $\mathrm{x}$ & \\
\hline & Nuttallides truempyi (Nuttall) & & & & & & & & & I \\
\hline & Nuttallides cf. florealis (White) & & & & & & & & $\mathrm{x}$ & \\
\hline & Calcareous benthic foraminifera & & I & & & & & & & \\
\hline \multirow{12}{*}{ 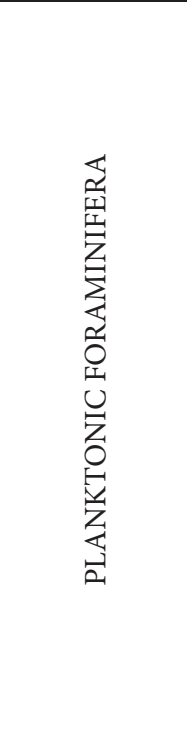 } & Acarinina bullbrooki (Bolli) & & & & & & I & & & \\
\hline & Chiloguembelina crinita (Glaessner) & & & & & & & & $\mathrm{x}$ & \\
\hline & Morozovella crater (Hornibrook) & & & & & & & & $\mathrm{x}$ & \\
\hline & Morozovella aragonensis (Nuttall) & & & & & & & & $\mathrm{x}$ & \\
\hline & Morozovella spp. & & & & & & & & $\mathrm{x}$ & \\
\hline & Subbotina criociapertura Blow & & & & & & & & $\mathrm{x}$ & \\
\hline & Subbotina eocaena (Guembel) & & & & & & & & $\mathrm{x}$ ? & \\
\hline & Subbotina linaperta (Finaly) & & & I & I & & I & & $\mathrm{x}$ & \\
\hline & Subbotina cf. linaperta (Finaly) & & & I & I & & I & & & \\
\hline & Subbotina patagonica (Todd and Kniker) & & & & & & & & $\mathrm{x}$ & \\
\hline & Subbotina yeguaensis (Weinzierl and Applin) & & & & & & & & $\mathrm{x}$ & \\
\hline & Subbotina spp. & & & & I & & I & & $\mathrm{x}$ & \\
\hline
\end{tabular}

I: 1-4 specimens per sample; II: 5-9; V: 10-19; X: 20-49; W: 50-99; Z: 100-199; H: 200-499; F: >500; x - presence. 


\section{LITHOSTRATIGRAPHY}

\section{Szczawnica Formation}

The Paleocene-Lower Eocene Szczawnica Formation forms the oldest lithostratigraphic unit in the investigated area (Figs 2-4).
The formation name was derived from the town of Szczawnica (Birkenmajer \& Oszczypko 1989). The best outcrop of this formation is located, however, in Łąkcica near Krościenko on the right bank of the Dunajec River (Chrustek et al. 2005).

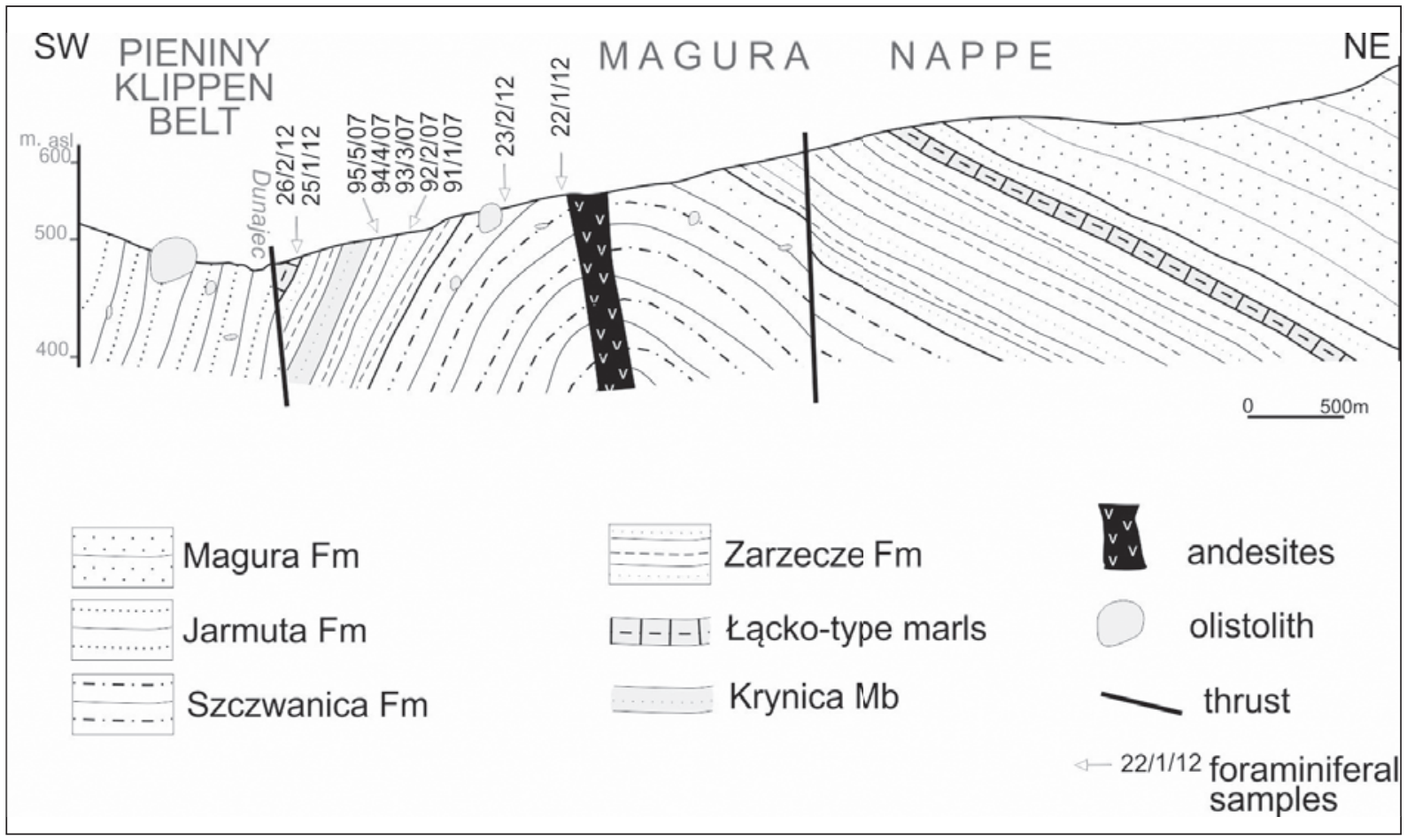

Fig. 3. Cross-section of the Ścigocki anticline (cross-line location in Figure 2)

The rocks in this outcrop are almost identical with the Ropianka Formation in the Bystrica and Rača units of the Magura Nappe. The Ropianka Formation was not, however, formally described from the Magura Nappe, therefore we use the formal name Szczawnica Formation. The Szczawnica Formation crops out in the central part of the Ścigocki valley, above the old mill in the core of the anticline (Fig. 2). It is represented by thin layers of gray sandstones, mudstones and claystones (Fig. 5). Thick conglomerates and sandstones of the Magura type occur also in this area, however, the separate thick-bedded Życzanów Member cannot be distinguished here. Part of the Szczawnica Formation consist of an olistostrome (Golonka et al. 2015). The matrix is not very well exposed. The olistolith consisting of Jurassic-Lower Cretaceous rocks crops out in the central part of the anticline (Fig. 2).

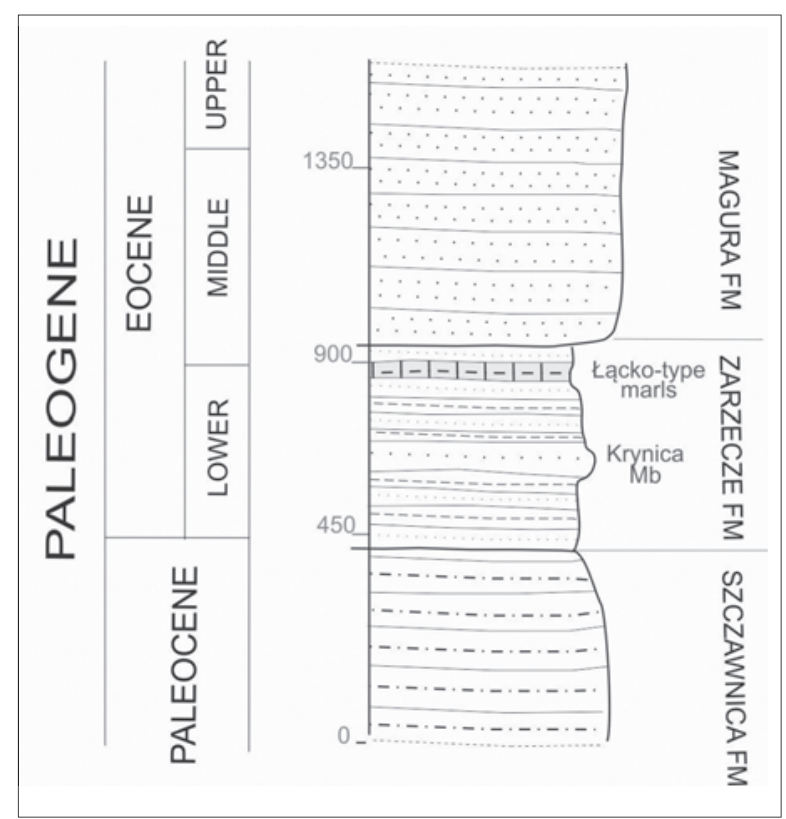

Fig. 4. Lithostratigraphical log of the Krynica zone in the Krościenko - Szczawnica area 

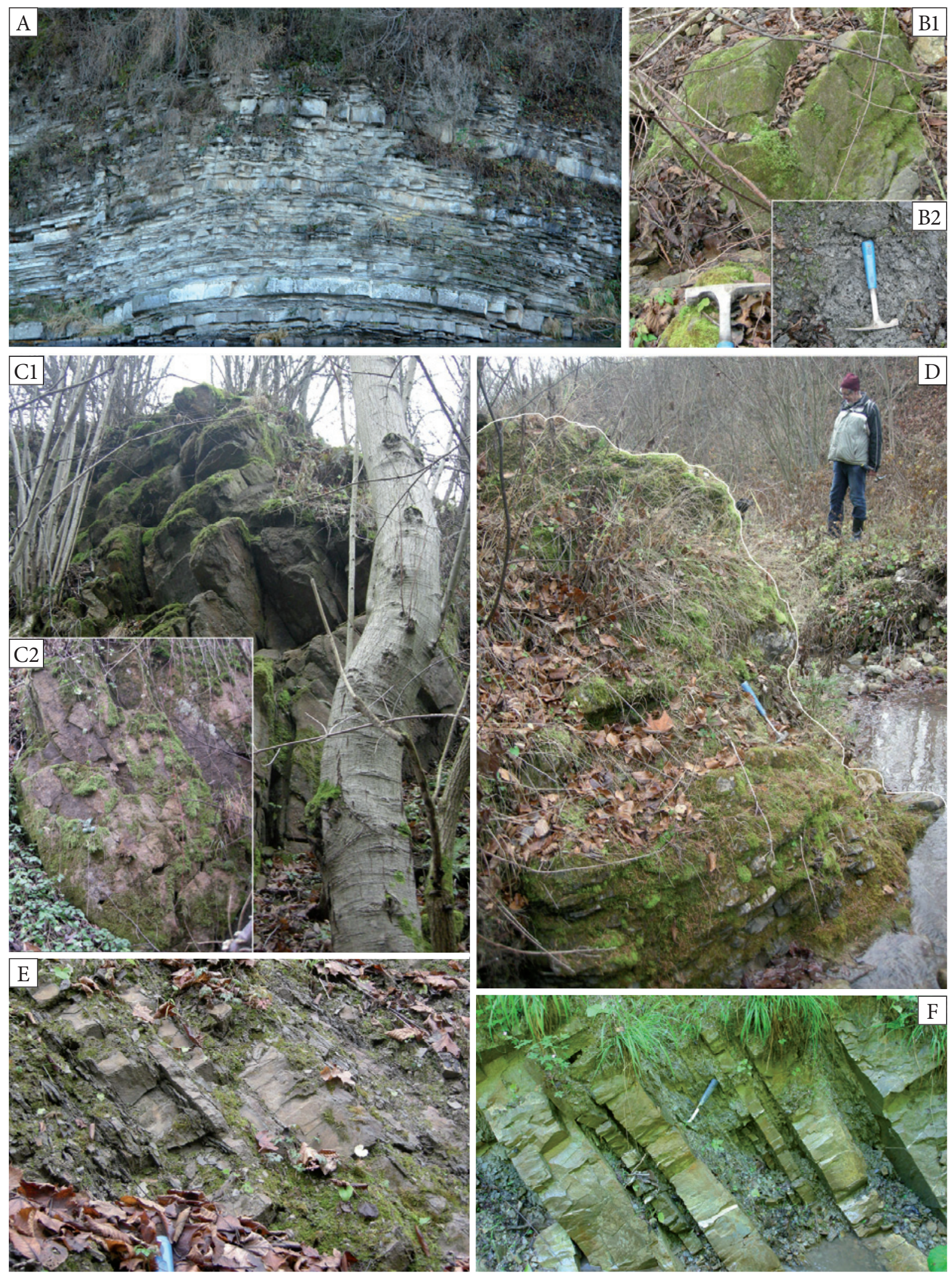

Fig. 5. The Paleogene deposits in the Ścigocki valley: A) flysch of the Szczawnica Formation; B) thick-bedded sandstones (1) and gray shales (2) within the Szczawnica Formation; C) andesitic dykes; D) olistolithic limestone block (outlined in white) within the Szczawnica Formation; E), F) flysch of the Zarzecze Formation 
The half-meter thick green radiolarites are covered by $2.5 \mathrm{~m}$ thick Maiolica-type cherty limestone with numerous Nannoconus div. sp. (main builder), radiolarites, and rare dinocysts Stomiosphaere wanneri Borza (Golonka \& Sikora 1981) (Fig. 5). This rock resembles limestones of the Pieniny Limestone Formation known from the Pieniny Mountains (Birkenmajer 1977). It was probably deposited on the northern slope of the Czorsztyn Ridge.

\section{Zarzecze Formation (Fig. 6)}

The Szczawnica Formation is covered by the Eocene Zarzecze Formation, which is similar to the Beloveža Formation from Bystrica and Rača units of the Magura Nappe (Golonka \& Waśkowska 2012).
The 300-meters thick Zarzecze Formation is exposed on the southern and northern limbs of the anticline in the lower and upper part of the Ścigocki valley as well as on the right bank of the Dunajec River near the St Kinga Chapel (Figs 2-4). The outcrop of this formation near the old mill in the Ścigocki valley was well known as a classic site of the Carpathian flysch. It was visited by earth scientist and geology students. Recently it is not so well exposed, and the access to the outcrop is somewhat difficult. The Zarzecze Formation in the old mill outcrop consist of thin- and medium-bedded fine-grained, grey mainly calcareous sandstones, alternating with shales (siltstones and mudstones) (Fig. 5). The Krynica Member, which consists of thick-bedded sandstones occurs within
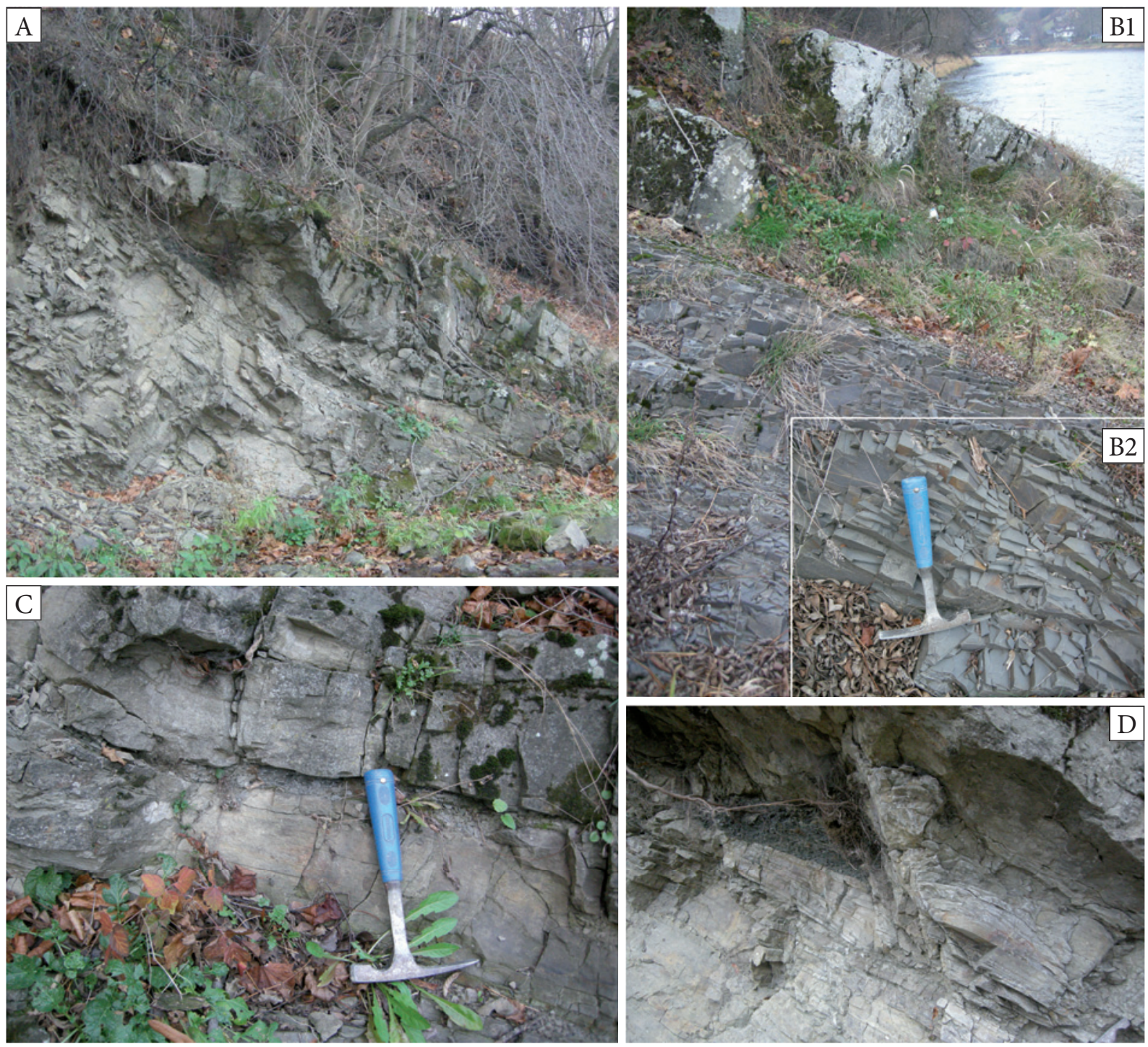

Fig. 6. The Zarzecze Formation in the Dunajec River banks: A) submarine slump within the Zarzecze Formation; B) the Eackotype marls within the Zarzecze Formation; C), D) submarine slump - details 
the Zarzecze Formation below the old mill in the lower of the Ścigocki valley in the southern limb of the anticline. It was not observed in the upper part of the Ścigocki valley in the northern limb of the anticline. The limited occurrence of this member indicates that it was deposited locally within channels filled with coarser material. The channels belonged to a fan with dominant thin-bedded turbidites. The thickness of the sandstone package is around $100 \mathrm{~m}$. Thick-bedded fine-, medium- and coarse-grained sandstones are intercalated with shales, mudstones, and thin-bedded turbidites. Conglomerates were not observed in the Ścigocki stream area. The intercalation of the Łącko-type marls is found in the tributary of the Ścigocki stream in the northern limb of the anticline and in the left bank of the Dunajec River in the southern limb of the anticline (Chrustek et al. 2005) (Fig. 6). These intercalations were assigned by Birkenmajer \& Oszczypko (1989) to the Szczawnica Formation in locality near the Zawiasy to the south of Krościenko on the left bank of the Dunajec River beneath of the St. Kinga Chapel. Oszczypko \& Oszczypko-Clowes (2010) reassigned them into the Eocene Zarzecze Formation. The submarine slump deposits are exposed within the Zarzecze Formation in this locality. These deposits consist of fragmented and plastically deformed sandstones layers, between which the small clasts of mudstones and marls occur.

\section{Magura Formation}

The thick-bedded sandstones of the Magura Formation cover conformably the Zarzecze Formation. The name Magura Formation was derived from the Oravská Magura Mountain Range in Slovakia. It was introduced by Paul (1868) and formally described by Birkenmajer \& Oszczypko (1989). It is characterized by thick-bedded predominantly fine- and medium-grained muscovite sandstones. The Magura Formation is represented in the investigated area by the Piwniczna Sandstone Member occurring in the northern limb of the anticline in the upper part of the Ścigocki stream and in the slopes of the Dzwonkówka Mountain, which belong to the Radziejowa Mountain Range of the Beskid Sądecki Mountains (Figs 2, 3). The name Piwniczna sandstones was introduced by Ostrowicka (1966; see also Golonka \& Rączkowski 1984) and formally defined by
Birkenmajer \& Oszczypko (1989). The Piwniczna Sandstone Member reaches $2000 \mathrm{~m}$ in thickness in the Dzwonkówka Mountain area. It is covered by the red shales of the Mniszek Shale Member in the Radziejowa Mountain Range (Ostrowicka 1966, Golonka \& Rączkowski 1984, Birkenmajer \& Oszczypko 1989, Oszczypko \& Oszczypko-Clowes 2010).

\section{BIOSTRATIGRAPHY}

Two micropaleontological samples were collected in the upper part of the Ścigocki valley, in the central part of anticline, from gray marly mudstone intercalations between thick-bedded sandstones (Fig. 2). Sample no 22/1/12 was taken below the southern outcrop of andesite and have not provided satisfactory biostratigraphical results (Tab. 1). Only a few tubular Bathysiphon forms were present. The next sample, no 23/2/12, was collected from deposits cropping out about $50 \mathrm{~m}$ north of the Ścigocki olistolith and it enable recognition of a more numerous and taxonomically varied assemblage of cosmopolitan agglutinated foraminifera; the species Haplophragmoides mjatliukae Maslakova was recognized among the others (Tab. 1). This species is known from the Outer Carpathian Paleocene (Waśkowska-Oliwa 2005, 2008, Cieszkowski et al. 2007, Bubik 2008) and is one of two indicatory taxa for the Paleocene foraminiferal biozone Rzehakina fissistomata in the standard zonation of the Outer Carpathians (Olszewska 1997). The presence of Haplophragmoides mjatliukae Maslakova provides the basis for assigning a Paleocene age to theese deposits. Moreover Remesella varians (Glaessner), Annectina grzybowskii (Jurkiewicz) and Hormosina velascoensis (Cushman) co-occur (Tab. 1, Figs 7, 8). These species are common in Carpathian assemblages from the Maastrichtian to the Paleocene (e.g., Jurkiewicz 1967, Jednorowska 1975, Geroch \& Nowak 1984, Olszewska et al. 1996, Bąk 2004, Kaminski \& Gradstein 2005, Waśkowska-Oliwa 2005, Cieszkowski et al. 2007, and citations therein).

Next, five samples were taken south of the Ścigocki olistolith (Fig. 2) from gray-greenish mudstones intercalated by medium- and thin-bedded (rarely thick-bedded) sandstones. Juvenile specimens of Reticulophragmium amplectens (Grzybowski) are present in all assemblages (Tab. 1, Fig. 8). 


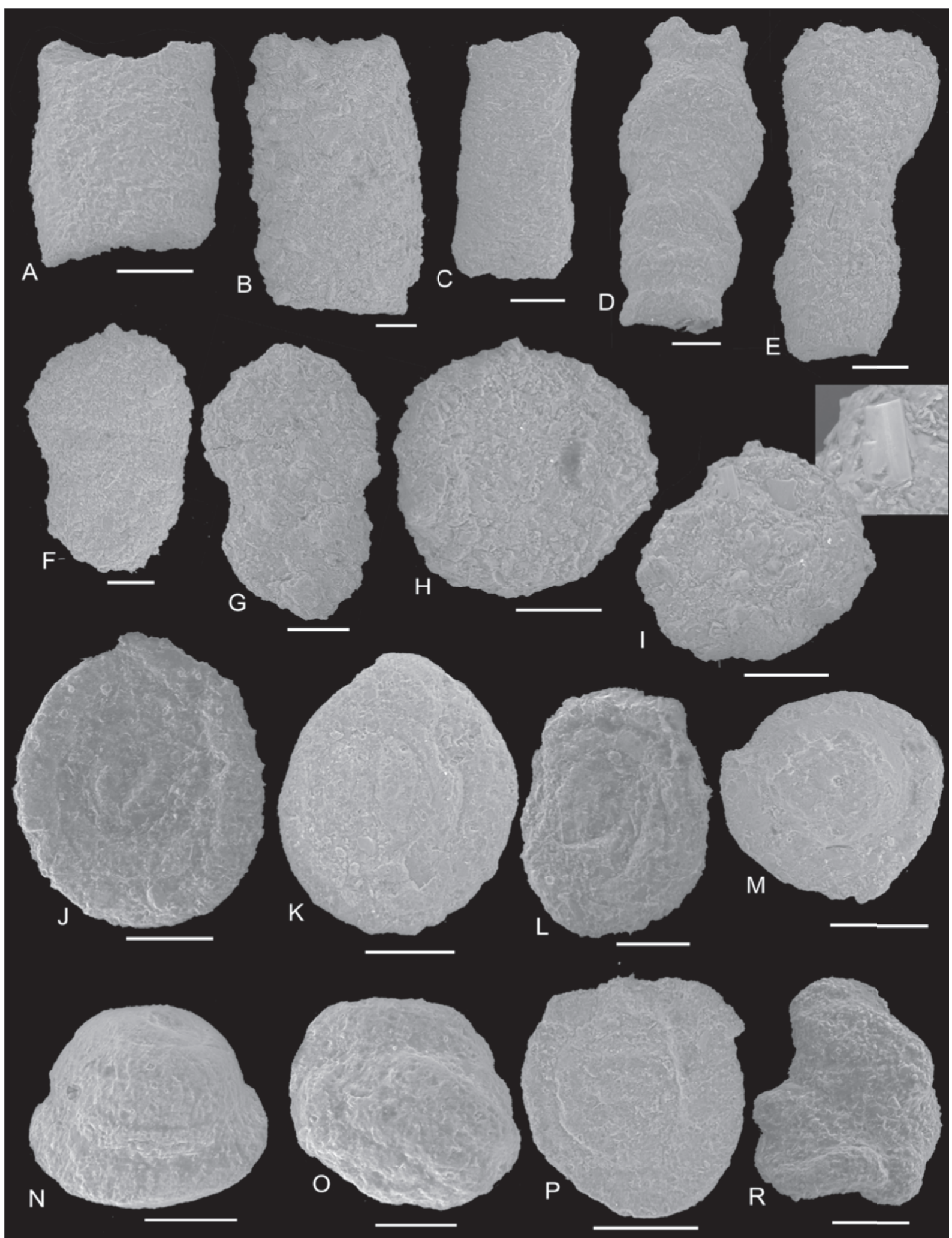

Fig. 7. Foraminifera from the studied section: A) Bathysiphon sp., sample (s.) 91/1/07; B) Bathysiphon sp., s. 93/3/07; C) Bathysiphon sp., s. 92/2/07; D) Pseudonodosinella nodulosa (Grzybowski), s. 91/1/07; E) Subreophax pseudoscalaris (Grzybowski), s. 92/2/07; F) Hormosina trinitatensis Cushman et Renz, s. 93/3/07; G) Reophax duplex Grzybowski, s. 95/5/07; H) Placentammina placenta (Grzybowski), s. 91/1/07; I) Placentammina placenta (Grzybowski) with incorporated tourmaline, s. 95/5/07; J) Ammodiscus sp./Dolgenia sp., s. 95/4/07; K) Ammodiscus tenuissimus Grzybowski, s. 91/1/07; L) Glomospira sp./Dolgenia sp., s. 95/5/07; M), N), O) Glomospira charoides (Jones et Parker), s. 94/4/07; P) Dolgenia sp., s. 92/2/07; R) Glomospira glomerata (Grzybowski), s. 95/5/07. Scale bar $=100 \mu \mathrm{m}$ 


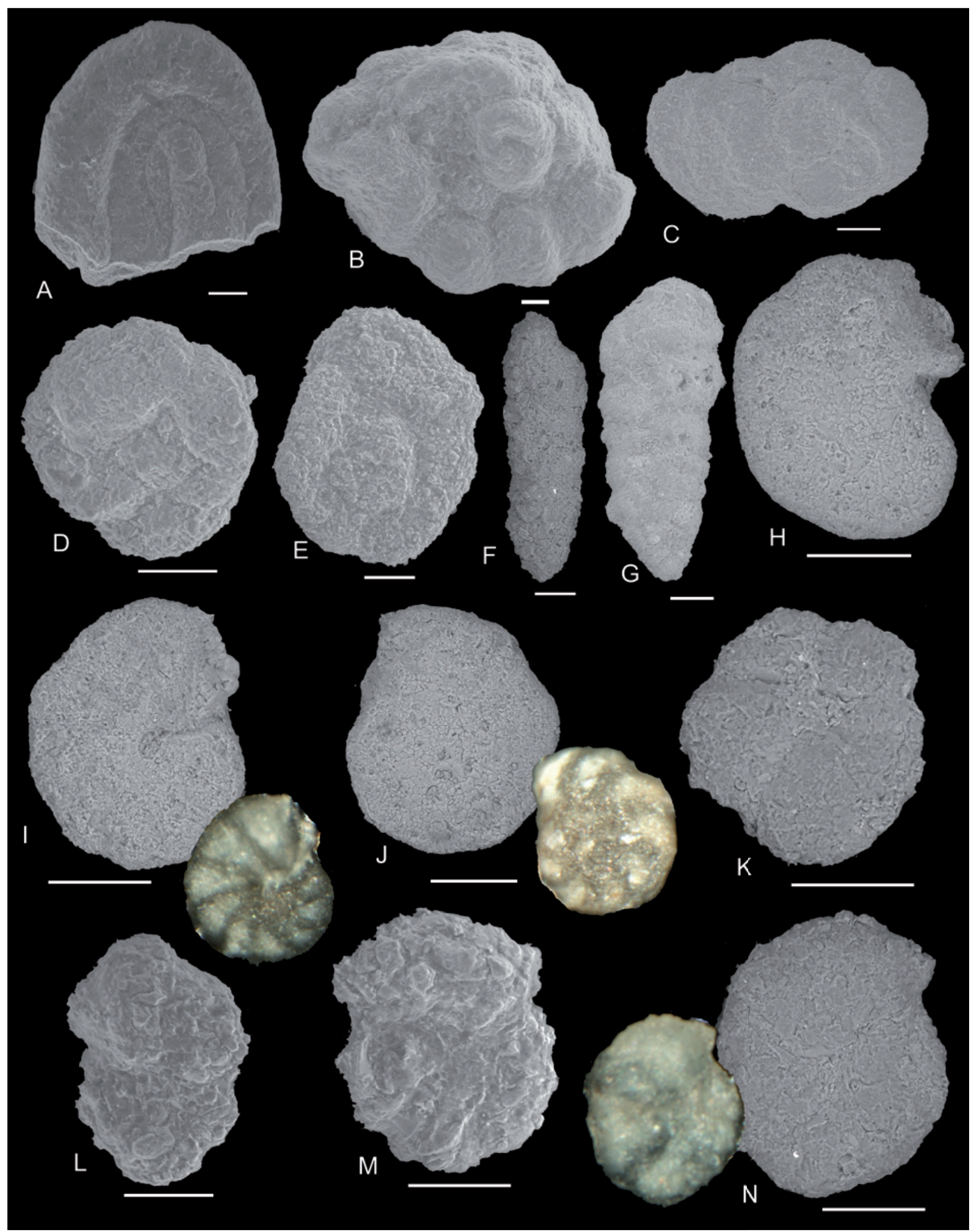

Fig. 8. Foraminifera from the studied section: A) Annectina grzybowskii (Jurkiewicz), s. 23/2/12; B) Paratrochamminoides acervulatus (Grzybowski), s. 23/2/12; C) Trochamminoides subcoronatus (Grzybowski), s. 23/2/12; D) Trochamminoides variolarius (Grzybowski), s. 23/2/12; E) Trochamminoides sp., s. 26/2/12; F) Karrerulina conversa (Grzybowski), s. 23/2/12; G) Spiroplectammina navarroana Cushman, s. 94/4/07; H), I) and J) Reticulophragmium amplectens (Grzybowski), s. 94/4/07; K) Haplophragmoides sp., s. 91/1/07; L) Haplophragmoides porrectus Maslakova, s. 91/1/07; M) Haplophragmoides horridus (Grzybowski), s. 94/4/07; N) Haplophragmoides mjatliukae (Maslakova), s. 23/2/12. Scale bar = $100 \mu \mathrm{m}$ 
Reticulophragmium amplectens (Grzybowski) is common in the Carpathian Eocene and is an index form for the Lutetian foraminiferal biozone (Geroch \& Nowak 1984, Olszewska 1997). Its first occurrence is known from the late Ypresian, within the Saccamminoides carpathicus zone (e.g., Jurkiewicz 1967, Morgiel \& Szymakowska 1978, Morgiel \& Olszewska 1981, Geroch \& Nowak 1984, Bąk et al. 1997, Olszewska 1997, Kaminski \& Gradstein 2005, Cieszkowski et al. 2006, Waśkowska 2011b, and citations therin). Cibicidoides praemundulus Berggren et Miller and Pseudonodosinella elongata (Grzybowski) indicate an Eocene age of the deposits (Bolli et al. 1994, Olszewska 1996, Holbourn et al. 2013). Praesphaerammina gerochi Hanzlíková, which is present in studied assemblages (in sample 91/1/07 quite numerous) (Tab. 1) is often found in Paleocene strata (Jurkiewicz 1967, Olszewska et al. 1996, Kaminski \& Filipescu 2000). Its last occurrence is recorded from the Early Eocene (Bąk 2004, Kaminski \& Gradstein 2005, Bubik 2006) and in this time interval it can co-occur with Reticulophragmium amplectens (Grzybowski). The two species were recognized within an assemblage with poorly preserved planktonic foraminifera - long ranging Eocene species Subbotina linaperta (Finlay) and Acarinina bullbrooki (Bolli) (Tab. 1), which have a total stratigraphic range from late Ypresian to Lutetian (Krasheninnikov \& Pflaumann 1977, Toumarkine \& Lutembacher 1985, Pearson et al. 2006, BouDagher-Fadel 2012). The presence of Acarinina bullbrooki (Bolli) also confirms estimated Ypresian to Lutetian age of the studied deposits.

The last two samples were collected in the Dunajec River valley, slightly below the St. Kinga Chapel (Fig. 2). Both samples were collected from soft rocks within chaotic deposits. Sample 25/1/12 was collected from clasts of gray marly shales. The foraminiferal assemblage is represented by poorly preserved planktonic forms with an admixture of calcareous benthos (Tab. 1). The plankton is dominated by the Subbotina genus. Several forms were identified e.g., Subbotina linaperta (Finaly), Subbotina criociapertura Blow, Subbotina eocaena (Guembel), Subbotina yeguaensis (Weinzierl and Applin) (Fig. 9). The first occurrences of these forms happened during late Ypresian times. Morozovella crater (Hornibrook) and Morozovella aragonensis (Nuttall) are observed in the upper Ypresian in this assemblage, indicative of the latest Ypresian to earliest Lutetian (Jenkins 1993, Berggren \& Persson 2005, Pearson et al. 2006, BouDagher-Fadel 2012). This occurrence determines the latest Ypresian to earliest Lutetian age of the studied shaly clasts.

Sample 26/2/12 was taken from gray mudstones incorporated as clasts into chaotic deposits. It contains numerous benthic foraminifera assemblages dominated by the cosmopolitan and long-ranging genera Recurvoides, Paratrochamminoides-Trochamminoides, Glomospira and Karrerulina. Glomospira and Karrerulina usually are present as minor components of the Outer Carpathians assemblages. The Early Eocene times provide a notable exception. These taxa display an acme after Late Paleocene times when deep-water conditions were affected by the Thermal Maximum crisis (e.g., Jurkiewicz 1967, Bubik 1994, 1995, Bąk et al.1997, Waśkowska 2000, 2011a, Bąk 2004, Kaminski 2005, Oszczypko et al. 2005, Cieszkowski et al. 2011, and citation therein). The Glomospira acme has biostratigraphical value indicating an early Ypresian age in the Carpathians (e.g., Morgiel \& Olszewska 1978, Olszewska 1997, Bąk 2004, Cieszkowski et al. 2011, and citation therein). The number of Glomospira is lower in upper Ypresian deposits (lower part of the Saccamminoides carpathicus biozone), but is still significant while numerous Recurvoides, Paratrochamminoides and Trochamminoides co-occur in this assemblage (Jurkiewicz 1967, Bąk et al. 1997, Bąk 2004, Cieszkowski et al. 2006, Waśkowska 2011a). Particularly a relatively high number of Karrerulina was present during late Ypresian times (Bąk 2004, Kaminski \& Gradstein 2005, Cieszkowski et al. 2011, Waśkowska-Cieszkowski 2014). Thus, the studied assemblage is very similar to Ypresian cosmopolitan Carpathian assemblages, suggest an Ypresian age for the collected sample. Also the co-occurrence of Hormosinella carpenter Brady (Holbourn et al. 2013, Jones 1994) appearing in Late Paleocene together with Cibicidoides praemundulus Berggren et Miller appearing in Ypresian (Olszewska et al. 1996, Holbourn et al. 2013) confirms an Eocene age of the foraminifera assemblage. Taking into account biostratigraphical data, the studied deposits cannot be older than the incorporated clasts, thus they are not older than late Ypresian - early Lutetian. 


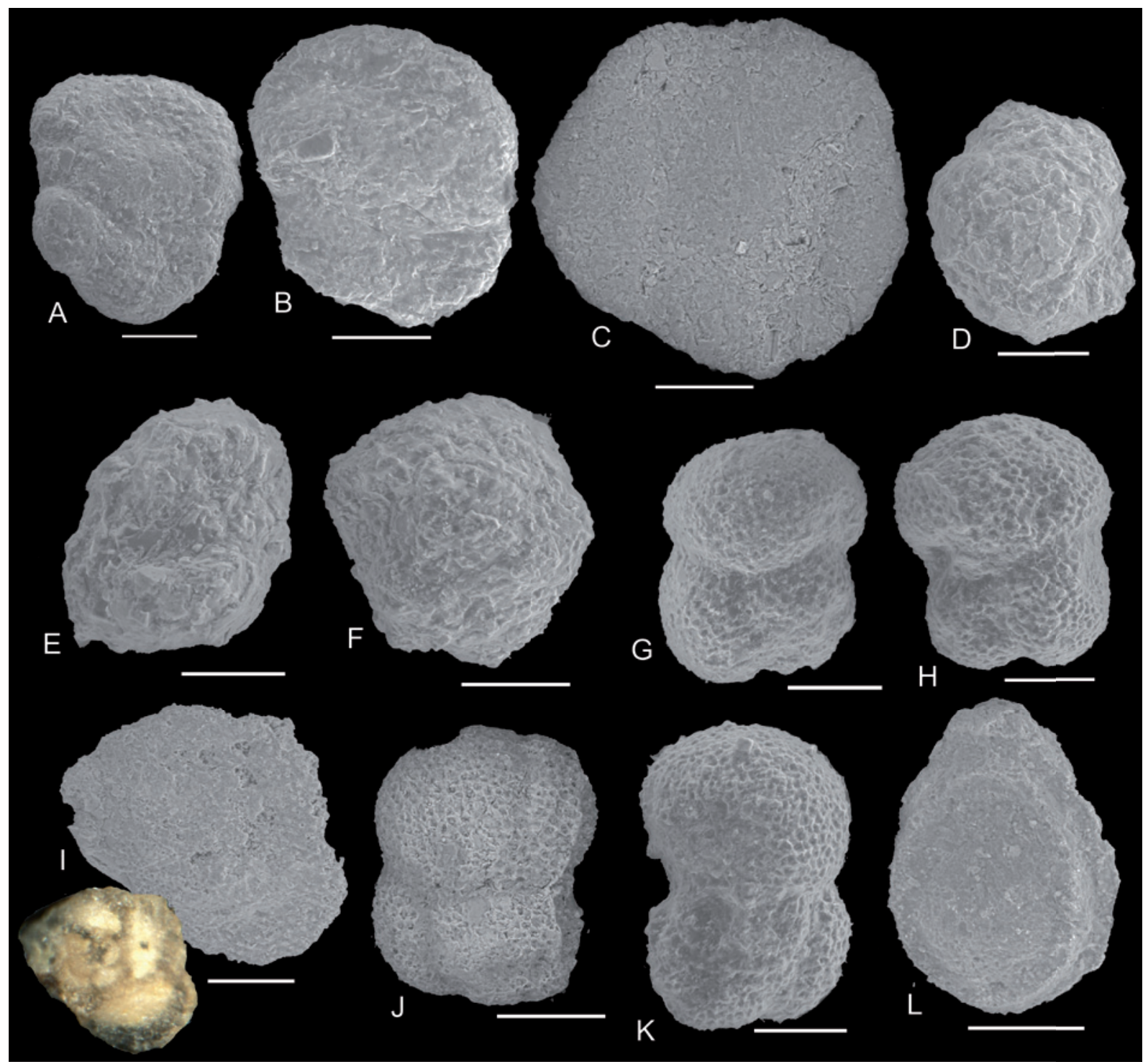

Fig. 9. Foraminifera from the studied section: A), B) Ammosphaeroidina pseudopauciloculata (Mjatliuk), s. 91/1/07; C) Praesphaerammina subgaleata Vasicek, s. 92/2/07; D) Thalmannammina subturbinata (Grzybowski), s. 91/1/07; E) Recurvoides walteri (Grzybowski), s. 95/5/07; F) Thalmannammina subturbinata (Grzybowski), s. 95/5/09; G) H) Subbotina patagonica (Todd and Kniker), s. 25/2/12; I) Morozovella crater (Hornibrook), s. 25/2/12; J) Subbotina linaperta (Finaly), s. 94/4/07; K) Subbotina criociapertura Blow, s. 25/2/12; L) Fissurina sp., s. 25/2/12. Scale bar $=100 \mu \mathrm{m}$

\section{DISCUSSION}

The flysch deposits of the Krynica zone of the Magura Nappe build the peri-Pieniny zone. Interpretation of the geological structure of this area is somewhat problematic. On one hand complex tectonics, on the other hand the fairly monotonous lithology of the deposits and the lack of continuous outcrops complicate the geology. The different flysch deposits belong to the various formations distinguished within the Paleogene rocks of the Krynica zone. The determination of these formations is obscured by the rather wide spectrum of lithological variability.
A sequence of Paleocene-Eocene flysch is exposed in the anticline distinguished in the Ścigocki stream section (Figs 2,3). Deposits of the Zarzecze Formation constitute the limbs of this anticline. An Early Eocene (to Middle Eocene?) age was established on the base of foraminiferal assemblages. These assemblages were found within the shaly intervals of turbidites from lower and middle part of formation, as well as from the submarine slump present in its upper part. The typical Zarzecze Formation is characterized by thin- and medium-bedded flysch deposits containing thick-bedded sandstones and 
Łącko-type marls. The obtained data significantly changes the geological map of the peri-Pieniny zone between Szczawnica and Krościenko, where mainly the Szczawnica Formation was previously distinguished (Birkenmajer \& Oszczypko 1989, Chrustek et al. 2005). Deposits of this formation are building only the central part of the Ścigocki anticline (Figs 2, 3). The Szczawnica Formation contains olistolithic blocks of Mesozoic calcareous and biosiliceous rocks. It is cut by andesitic dykes.

The boundary between the Krynica zone of the Magura Nappe and the Pieniny Klippen Belt in Poland was distinguished mainly on the basis of tectonics (Golonka \& Rączkowski 1981, Kulka et al. 1987, Birkenmajer \& Oszczypko 1989, Chrustek et al. 2005). Deposits older than Late Cretaceous do not crop out in the Krynica zone. All deposits are allochthonous in character. The Pieniny Klippen Belt also includes Upper Cretaceous-Oligocene rocks deposited within the Magura Basin. The facies changes are difficult to distinguish because of tectonic disturbance. The uppermost Cretaceous-Paleocene deposits within the Magura Basin are widespread both in the Magura Nappe, were they known as the Szczawnica Formation as well as in the Pieniny Klippen Belt, known as the Jarmuta Formation. Both formations include coarse-grained sandstones, conglomerates, and olistostromes with Jurassic and Cretaceous calcareous rocks. The amount of these deposits greatly increases in the Jarmuta Formation indicating the more proximal character of the deposition. The Szczawnica and Jarmuta formations are quite closely related, representing proximal and distal facies of slope and rise turbidites. The younger deposits are cropping out mainly in the Krynica zone. Their character changes vertically between the Zarzecze and Magura formations.

\section{CONCLUSIONS}

The Magura Nappe in the peri-Pieniny zone between Krościenko and Szczawnica contain a significant amount of the Zarzecze Formation in the area previously mapped as the Paleocene Szczawnica Formation. The Zarzecze Formation deposits consisting mainly of thin- and medium-bedded turbidites occur in the limbs of the Scigocki anticline. Packets of thick-bedded sandstones form the Krynica Member in the middle part of the Zarzecze
Formation. The carbonate deposits of Łącko-type marls occur in the upper part of the formation.

The Ypresian - early Lutetian age of the Zarzecze Formation is established based on foraminiferal assemblages collected within the shaly parts of turbidities. They assemblages contain Acarinina bullbrooki (Bolli), Cibicidoides praemundulus Berggren et Miller, Pseudonodosinella elongata (Grzybowski), Praesphaerammina gerochi Hanzlíková and Reticulophragmium amplectens (Grzybowski). The assemblages from the submarine slump in upper part of the Zarzecze Formation suggest a similar age.

The Paleocene Szczawnica Formation forms the core part of the Ścigocki anticline. The block, occurring within flysch deposits, consisting of Jurassic and Cretaceous carbonate and siliceous rocks, and has an olistolithic character. The olistoliths within the Jarmuta Formation occur in a similar position.

This research has been financially supported by AGH University of Science and Technology in Krakow grant no. 11.11.140.173. Thanks are extended to Teresa Wójcik (WGGiOŚ AGH) for help in preparation of the micropaleontological samples. Authors are grateful for the constructive comments on manuscript received from Michael A. Kaminski (KFUPM) and Marek Cieszkowski (UJ).

\section{REFERENCES}

Alexandrowicz S.W., Bogacz K. \& Węcławik S., 1966. Les grés á Lithothamnium dans le flysch de Magura des environs de Krościenko sur Dunajec. Zeszyty Naukowe AGH 123, Geologia 7, 39-61.

Alexandrowicz S.W., Cieszkowski M., Golonka J., Kutyba J., Oszczypko N. \& Paul Z., 1984. Stratygrafia strefy krynickiej płaszczowiny magurskiej w polskich Karpatach fliszowych; The stratigraphy of the Krynica Zone of the Magura Nappe in the Polish Flysch Carpathians. Biuletyn Instytutu Geologicznego, 340, 23-43.

Bąk K., 2004. Deep-water agglutinated foraminiferal changes across the Cretaceous/Tertiary and Paleocene/Eocene transitions in the deep flysch environment; eastern Outer Carpathians (Bieszczady Mts, Poland). [in:] Bubik M. \& Kaminski M.A. (eds), Proceedings of the Sixth International Workshop on Agglutinated Foraminifera, Grzybowski Foundation Special Publication Series, 8, 1-56.

Bąk K., Bąk M., Geroch S., \& Manecki M., 1997. Biostratigraphy and paleoenvironmental analysis of benthic foraminifera and radiolarians in Paleogene variegated shales in the Skole unit, Polish Flysch Carpathians. Annales Societatis Geologorum Poloniae, 67, 135-154. 
Berggren W.A. \& Pearson P.N., 2005. A revised tropical to subtropical Paleogene planktonic foraminiferal zonation. Journal of Foraminiferal Research, 35, 279-298.

Birkenmajer K. \& Oszczypko N., 1989. Cretaceous and Paleogene lithostratigraphic units of the Magura Nappe, Krynica Subunit, Carpathians. Rocznik Polskiego Towarzystwa Geologicznego, 59, 145-181.

Birkenmajer K., 1957. Dajki andezytowe góry Bryjarki w Szczawnicy. Przegląd Geologiczny, 2, 62-65.

Birkenmajer K., 1977. Jurassic and Cretaceous lithostratigraphic units of the Pieniny Klippen Belt, Carpathians, Poland. Studia Geologica Polonica, 45, 1-159.

Bogacz K. \& Węcławik S., 1962. The Geological Position of the "Boundary Flysch" (Nordliche Grenzzone) on the Southern Slopes of the Gorce Mountains. Bulletin of the Polish Academy of Sciences, 10, 223-229.

Bolli H.M., 凶Beckmann J.P. \& \Saunders J.B., 1994. Benthic Foraminiferal Biostratigraphy of the South Caribbean Region. Cambridge University Press.

BouDagher-Fadel M.K., 2012. Biostratigraphic and Geological Significance of Planktonic Foraminifera. Developments in Palaentology and Stratigraphy, 22, 1-289.

Bubík M., 1994. Bioevents at the Paleocene/Eocene boundary in flysch sediments of the Biele Karpaty Unit (West Carpathians, Czech Republic). Geolines, 1, 3-5.

Bubík M., 1995. Cretaceous to Paleogene agglutinated foraminifera of the Biele Karpaty unit (West Carpathians, Czech Republic). [in:] Kaminski M.A., Geroch S. \& Gasinski M.A. (eds), Proceedings of the Fourth International Workshop on Agglutinated Foraminifera, Grzybowski Foundation Special Publication, 3, 71-116.

Bubík M., 2006. Results of mapping and stratigraphic research in the Silesian Unit on the Horní Bečva map sheet. Zprávy o geologických výzkumech v roce 2006, 9-14.

Chrustek M., Golonka J., Janeczko A. \& Stachyrak F., 2005. Geological characterisation of the Krynica Subunit in the vicinity of Krościenko on the Dunajec River (Magura Nappe, Outer Flysch Carpathians). Geologia - Kwartalnik Akademii Górniczo-Hutniczej im. Stanisława Staszica w Krakowie, 31, 1, 127-144.

Cieszkowski M., 1985. Stop 22: Obidowa. [in:] Birkenmajer K. (ed.), Carpatho-Balkan Geological Association XIII Congress: Cracow, Poland, 1985. Main geotraverse of the Polish Carpathians (Cracow - Zakopane): guide to excursion 2, Wydawnictwa Geologiczne, Warszawa, $48-54$.

Cieszkowski M., Ślączka A. \& Wdowiarz S. 1985b. New data on structure of the flysch Carpathians. Przeglad Geologiczny, 33, 6, 313-333.

Cieszkowski M. \& Oszczyplo N., 1985. Rozwój osadów płaszczowiny magurskiej w strefie przypienińskiej [English summ.]. Przegląd Geologiczny, 34, 227-334.

Cieszkowski M., Golonka J., Krobicki M., Slączka A., Oszczypko N., Waśkowska A. \& Wendorff M., 2009. The Northern Carpathians plate tectonic evolutionary stages and origin of olistoliths and olistostromes. Geodinamica Acta, 22, 1-26.

Cieszkowski M., Golonka J., Waśkowska-Oliwa A. \& Chodyń R., 2007. Type Locality of the Mutne Sandstone Member of the Jaworzynka Formation, Western Outer Carpathians, Poland. Annales Societatis Geologorum Poloniae, 77, 269-290.
Cieszkowski M., Leśniak T., Środoń J. \& Waśkowska-Oliwa A., 2006. Bentonitized tuffites in the Lower Eocene deposits of the Subsilesian Unit (Wester Outer Carpathians, Poland). Annales Socetatis Geologorum Poloniae, 76, 197-214.

Cieszkowski M., Waśkowska A. \& Kaminski M.A., 2011. Deep-water agglutinated foraminifera in Paleogene hemipelagic sediments of the Magura Basin in the Sucha Beskidzka area - variegated shales of the Łabowa Shale Formation. [in:] Bąk M., Kaminski M.A. \& Waśkowska A. (eds), Integrating Microfossil Records from the Oceans and Epicontinental Seas. Grzybowski Foundation Special Publication, 17, 53-63

Geroch S. \& Nowak W., 1984. Proposal of zonation for the late Tithonian - late Eocene, based upon arenaceous Foraminifera from the Outer Carpathians, Poland. [in:] Benthos '83: 2e Symposium International Sur Les Foraminifères Benthiques: Pau (France), 11-15/4/1983, Elf Aquitaine, 225-239.

Golonka J. \& Rączkowski W., 1984. Objaśnienia do szczegółowej mapy geologicznej Polski, skala 1 : 50 000, arkusz Piwniczna. Wydawnictwa Geologiczne, Warszawa.

Golonka J. \& Sikora W., 1981. Microfacies of the Jurassic and Lower Creataceous sedimentarily thinned deposits of the Pieniny Klippen Belt in Poland. Biuletyn Instytutu Geologicznego, 331, 7-37.

Golonka J. \& Waśkowska A., 2012. The Beloveža Formation of the Raca Unit in the Beskid Niski Mts.(Magura Nappe, Polish Flysch Carpathians) and adjacent parts of Slovakia and their equivalents in the western part of the Magura Nappe; remarks on the Beloveža Formation - Hieroglyphic Beds controversy. Geological Quarterly, 56, 821-832.

Golonka J., Cieszkowski M., Waśkowska A., Krobicki M. \& Ślączka A., 2010. Olistostromes of the Pieniny Klippen Belt, Northern Carpathians. Geologica Balcanica, 39, 137-138.

Golonka J., Krobicki M., Waśkowska A., Cieszkowski M. \& Ślączka A., 2015.Olistostromes of the Pieniny Klippen Belt, Northern Carpathians. Geological Magazine [in press].

Holbourn A., Henderson A.S. \& Macleod N., 2013. Atlas of benthic foraminifera. Wiley-Blackwell.

Jednorowska A., 1975. Small formaminferal asemblages in the Paleogene of the Western Carpathians. Studia Geologica Polonica, 47, 1-149.

Jenkins D.G., 1993. The evolution of the Cenozoic southern high- and mid-latitude planktonic foraminiferal faunas. The Antarctic Paleoenvironment: a Perspective on Global Change Antarctic Research Series, 60, 175-194.

Jones R.W., 1994. The Challenger Foraminifera. Oxford University Press.

Jurewicz E., 2005. Geodynamic evolution of the Tatra Mts. and the Pieniny Klippen Belt (Western Carpathians): problems and comments. Acta Geologica Polonica, 55, 295-338.

Jurkiewicz H., 1967. Otwornice paleogenu podmenilitowego polskich Karpat środkowych. Biuletyn Instytutu Geologicznego, 210, 5-128.

Kaminski M.A. 2005. The utility of deep-water agglutinated foraminifera for correlating Eocene to Oligocene abyssal sediments in the North Atlantic and Western Tethys. Studia Geologica Polonica, 124, 325-340.

Kaminski M.A. \& Filipescu S., 2000. Praesphaerammina, a new genus of Cenozoic agglutinated foraminifera 
from Carpathian flysch deposits. Micropaleontology, 46, 353-359.

Kaminski M.A. \& Gradstein F.M., 2005. Atlas of Paleogene cosmopolitan deep-water agglutinated foraminifera. Grzybowski Foundation Special Publication, 10, 1-547.

Kováč M. \& Plašienka D. (eds), 2002. Geological structure of the Alpine-Carpathian-Pannonian junction and neighboring slopes of the Bohemian Massif. Comenius University, Bratislava.

Koszarski L., Sikora W. \& Wdowiarz S., 1974. The Flysch Carpathians. Polish Carpathians. [in:] Mahel M. (ed.), Tectonics of the Carpathian-Balkan Region. Geologicky Ustav Dionyza Stura, 180-197.

Krasheninnikov V.A. \& Pflaumann V., 1977. Zonal stratigraphy and planktonic foraminifera Paleogene deposits of the Atlantic Ocean to the west of Africa. Deep Sea Drilling Project, Initial Report, 41, 581-611.

Kulka A., Rączkowski W., Żytko K. \& Paul Z., 1987. Szczegółowa mapa geologiczna Polski, skala 1:50 000, arkusz Szczawnica - Krościenko. Wydawnictwa Geologiczne, Warszawa.

Kulka A., Rączkowski W., Żytko K. \& Paul Z., 1991. Objaśnienia do szczegółowej mapy geologicznej Polski, skala 1:50 000, arkusz Szczawnica - Krościenko. Wydawnictwa Geologiczne, Warszawa.

Lexa J., Elecko M., Mello J., Polak M., Potfaj M. \& Vozar J. (eds), 2000. Geological Map of Western Carpathians and adjacent areas. Geological Survey of Slovak Republic, Bratislava.

Morgiel J. \& Olszewska B., 1981. Biostratigraphy of the Polish External Carpathians based on agglutinated foraminifera. Micropaleontology, 27, 1-30.

Morgiel J. \& Szymakowska F., 1978. Stratygrafia paleocenu i eocenu jednostki skolskiej. Biuletyn Instytutu Geologicznego, 310, 39-171.

Olszewska B., 1997. Foraminiferal biostratigraphy of the Polish Outer Carpathians: A record of basin geohistory. Annales Societatis Geologorum Poloniae, 67, 325337.

Olszewska B., Odrzywolska-Bieńkowa E., Giel M.D., Pożaryska K. \& Szczechura K., 1996. Eichwald, 1830. [in:] Malinowska L. \& Piwocki M. (eds), Atlas skamieniałości przewodnich i charakterystycznych. Cz. 3a, Kenozoik, Trzeciorzęd, Paleogen, Budowa Geologiczna Polski, 3 , Polska Agencja Ekologiczna, Warszawa, 45-215.

Ostrowicka H., 1966. Profil litologiczny gruboławicowych piaskowców w Piwnicznej. Sprawozdania z Posiedzen Komisji Naukowych - Państwowa Akademia Nauk, Oddział w Krakowie, 10, 608-611.

Oszczypko N. \& Oszczypko-Clowes M., 2010. The Paleogene and early Neogene stratigraphy of the Beskid Sądecki Range and Lubovnianska Vrchovina (Magura Nappe, Western Outer Carpathians). Acta Geologica Polonica, $60,317-348$.

Oszczypko N., 1979. Budowa geologiczna północnych stoków Beskidu Sądeckiego między Dunajcem a Popradem (płaszczowina magurska). Rocznik Polskiego Towarzystwa Geologicznego, 49, 293-325.

Oszczypko N., 1992. Rozwój basenu magurskiego w górnej kredzie i paleogenie. Przeglad Geologiczny, 7, 379404.
Oszczypko N., Malata E., Bąk K., Kędzierski M. \& Oszczypko-Clowes M., 2005. Lithostratigraphy, biostratigraphy and palaeoenvironment of the Upper Albian-Lower/ Middle Eocene flysch deposits in the Beskid Wyspowy and Gorce Ranges; Polish Outer Carpathians, Magura Nappe; Bystrica \& Rača subunits. Annales Societatis Geologorum Poloniae, 75, 27-69.

Paul C.M., 1868. Die nördliche Verhaltnisse nordlischen Saroser und Zempliner Comitates. Jahrbuch der Kaiserlich Königlichen Geologischen Reichsanstalt, 8, 27-46.

Pearson P.N., Olsson R.K., Huber B.T., Hemleben C. \& Berggren W.A., 2006. Atlas of Eocene planktonic foraminifera. Cushman Foundation for Foraminifera Research Special Publication, 41, 1-513.

Ślączka A., Kruglow S., Golonka J., Oszczypko N. \& Popadyuk I., 2006. The General Geology of the Outer Carpathians, Poland, Slovakia, and Ukraine. [in:] Golonka J. \& Picha F.J.(eds), The Carpathians and Their Foreland: Geology and Hydrocarbon Resources, American Association of Petroleum Geologists, Memoir, 84, 221-258.

Toumarkine M. \& Luterbacher H., 1985. Paleocene and Eocene planktonic foraminifera. [in:] Bolli H.M., Saunders J.B. \& Perch-Nielsen K. (eds), Planktonic Stratigraphy, Cambridge University Press, 87-154.

Uhlig V., 1890. Ergebnisse geologischer Aufnahmen in den westgalizischen Karpathen. Tail II. Der pieninische Klippenzug. Jahrbuch der Kaiserlich Königlichen Geologischen Reichsanstalt, 40, 559-824.

Waśkowska A. \& Cieszkowski M., 2014. Biostratigraphy and depositional anatomy of a large olistostrome in the Eocene Hieroglyphic formation of the Silesian Nappe, Polish Outer Carpathians, Annales Socetatis Geologorum Poloniae, 84, 51-70.

Waśkowska A., 2011a. Response of Early Eocene deep-water benthic foraminifera to volcanic ash falls in the Polish Outer Carpathians. Paleogeography, Paleoclimatology, Paleoecology, 305, 50-64.

Waśkowska A., 2011b. The Early Eocene Saccamminoides carpathicus assemblage in the Outer Flysch Carpathians. [in:] Kaminski M.A. \& Filipescu S. (eds), Proceedings of the Eighth International Workshop on Agglutinated Foraminifera, Grzybowski Foundation Special Publication, 16, 331-341.

Waśkowska-Oliwa A., 2000. Interpretacja biostratygraficzna i paleoekologiczna zespołów otwornic aglutynujacych z paleoceńsko-środkowo eoeńskich osadów płaszczowiny magurskiej w rejonie Suchej Beskidzkiej (Karpaty fliszowe). Przeglad Geologiczny, 48, 331-336.

Waśkowska-Oliwa A., 2005. Foraminiferal paleodepth indicators from the lower Palaeogene deposits of the Subsilesian Unit (Polish Outer Carpathians). Studia Geologica Polonica, 124, 297-324.

Waśkowska-Oliwa A., 2008. The Paleocene assemblages of agglutinated foraminifera from deep-water basin sediments of the Carpathians (Subsilesian Unit, Poland) biostratigraphical remarks. [in:] Kaminski M.A. \& Coccioni R. (eds), Proceedings of the Seventh International Workshop on Agglutinated Foraminifera, Grzybowski Foundation Special Publication, 13, 227-265.

Watycha L., 1963. Flisz magurski południowej części Gorców. Przeglad Geologiczny, 8, 371-378. 